This item was submitted to Loughborough's Research Repository by the author.

Items in Figshare are protected by copyright, with all rights reserved, unless otherwise indicated.

\title{
Sport and political ideology
}

PLEASE CITE THE PUBLISHED VERSION

https://www.routledge.com/Routledge-Handbook-of-Sport-and-Politics/Bairner-Kelly-

Lee/p/book/9781138792548

\section{PUBLISHER}

Routledge (Taylor \& Francis Group)

VERSION

AM (Accepted Manuscript)

\section{PUBLISHER STATEMENT}

This work is made available according to the conditions of the Creative Commons Attribution-NonCommercialNoDerivatives 4.0 International (CC BY-NC-ND 4.0) licence. Full details of this licence are available at: https://creativecommons.org/licenses/by-nc-nd/4.0/

\section{LICENCE}

CC BY-NC-ND 4.0

\section{REPOSITORY RECORD}

Bairner, Alan. 2019. "Sport and Political Ideology”. figshare. https://hdl.handle.net/2134/23092. 


\section{Sport and Political Ideology}

\section{Alan Bairner (Loughborough University)}

\section{Introduction}

As Hoberman (1984: 1) observed, 'The idea that sport is somehow an intrinsically political phenomenon has never been explained. In fact, sport is less known for its political character than for its legendary effects'. There is certainly no denying that 'across the ideological, class, cultural, and sporting spectrum, there seems to be a consensus that sports are, at best, distractingly vapid’ (Hern, 2013: 9). Yet if we are to understand fully the intrinsic political character of sport, there is arguably no better place to begin than with the ideological spectrum to which Hern refers. This chapter outline the trajectory of the concept of political ideology before offering an overview of the relationship between political ideologies and sport.

\section{Political ideologies}

According to Finlayson (2012: 751), 'The political theory of ideologies is an established subfield of political theory, distinguished by a commitment to studying political ideas as they are found "in the wild”'. It can be argued that 'ideologies are ubiquitous, intrinsic and necessary components of political life’ (Finlayson, 2012: 752). Thus, ‘The political theory of ideologies is concerned with the ubiquity, propriety and creativity of political thinking' (Finlayson, 2012: 757). The concept of ideology itself, however, has a chequered history. The word was first used in public in 1796 by Antoine Destutt de Tracy who regarded ideologie as a new 'science of ideas' (Heywood, 2003). His goal was to establish scientific truths on the basis of rational thought. However, although the European Enlightenment laid the foundations for the use of the word ideology in social scientific analysis, it was the development of the concept 
by Karl Marx and his followers that influenced subsequent theorisation to a greater extent.

For Marx, ideology involved delusion and lay at the heart of what was to become known as false consciousness, specifically the false consciousness of the working classes in capitalist societies (Marx and Engels, 1970). It is central to the maintenance of power in class societies. Marx also assumed that ideology's role is temporary and will disappear in the course of the transition to a communist world. To that extent, therefore, although influential, the Marxist use of the term differs markedly from its function in contemporary political science.

Karl Mannheim (1936) developed the concept still further, agreeing with Marx that ideological thinking is the product of social conditions, but removing the concept's negative implications. Even with this revision, however, ideologies were still be presented as thought systems which tend to defend the interests of dominant elites. Moreover, they offer partial, distorted and self-interested versions of social reality.

This understanding of ideology was given added credence with the rise of totalitarian regimes in the years between the First and Second World Wars. For some indeed, the twentieth century can legitimately be described as 'the age of ideologies' even though most, if not all, of the significant ideologies, had their roots in the nineteenth century or even earlier. Since the 1960s, however, as Heywood (2003: 11) notes, 'the term ideology has gained a wider currency through being refashioned according to the needs of conventional social and political analysis'. Thus, ideologies become action-oriented systems of thought. They are 'neither good nor bad, true nor false, open nor closed, liberating nor oppressive - they can be all these things (Heywood, 2003: 11). So what precisely does the term political ideology mean in the twenty-first century?? 
According to Heywood (2003: 5), 'To examine ‘ideology' is to consider a particular type of political thought, distinct from, say, political science or political philosophy'. On the other hand, 'To study political ideology is to analyse the nature, role and significance of this category of thought, and to reflect on questions such as which set of political ideas and arguments should be classified as ideologies’ (Heywood, 2003: 5). Here one can argue together with Marx, and to a lesser extent with Mannheim, that political ideologies are partial and distorted ways of seeing the world which are propagated by certain people to ensure that others, often an overwhelming majority of the population, accept a view of the world which allows the former to maintain their positions of power. Are some ideologies truer than others? Yes - but only if they serve one's own interests and/or accord with how one envisages what the world is now and what it could be.

Ideologies, according to Müller (2009: 213), 'were really a result of the loss of a belief in progress towards the end of the nineteenth century; they were an expression of "crisis thinking”, made up of dispersed and often incoherent fragments from "decayed thought systems"'. Although they are often located on a spectrum running from right to left, it might be more accurate to identify them at different points of a circle, thereby helping us to maintain an appropriate distance between those ideologies (communism and fascism) which in practice, if not necessity in theory, were more likely to promote the idea of a strong, interventionist state. 'The age of ideologies' is often equated with 'the age of extremes'. Yet, as Müller (2009: 213) observes, 'seeing the twentieth century as an age of ideological extremes or as an "age of hatred" is to fail to understand that ordinary men and women - and not just intellectuals and political leaders - saw many of these “ideologies” and the institutions that were justified with their help as real answers to their problems'. 
There are those who would have us believe that ideologies are increasingly irrelevant to the contemporary political landscape. For them, ideologies emerged in the late $18^{\text {th }}$ century and reached a crescendo during the $20^{\text {th }}$ century when most global political issue were linked in some way or another to competition between certain ideologies. It is certainly arguable that the function that has historically been served by ideologies is less needed in a world in which individualism appears to have become the dominant world view at least in most of the developed world. After all, to all intents and purposes ideologies offered people the means whereby they could think collectively or, if one was to be really harsh, not think at all but simply take the ideological manual down from the shelf and apply it to each and every circumstance that was faced.

As early as 1960, Daniel Bell announced the end of the concept of ideology.

The historicity of the term has lost its context, and only the pejorative and invidious penumbra, but no conceptual clarity, remains. Ideology has become an irretrievably fallen word (Bell, 1960: 447).

According to Bell (1960) ideology, which once was a road to action, has come to be an end'. It should be noted that most of Bell's opprobrium was directed towards socialism and, above all, Marxism. His successor, Frances Fukuyama, on the other hand, questioned the relevance of all systems of thought other than those which advocated liberal democracy coupled with a commitment to capitalist economics. In 1992, Fukuyama (2006: 39) argued that 'On both the communist Left and the authoritarian Right, there has been a bankruptcy of serious ideas capable of sustaining the internal political cohesion of strong governments, whether based on “monolithic” parties, military juntas, personalistic dictatorships’. Fukuyama (2006: 51) had arrived at the conclusion that 'The success of democracy in a wide variety of places and 
among many different peoples would suggest that the principles of liberty and equality on which they are based are not accidents or the results of ethnocentric prejudice, but are in fact discoveries about the nature of man as man, whose truth does not diminish but grows more evident as one's point of view becomes more cosmopolitan'.

It should be noted that Fukuyama (2010) himself has subsequently abandoned some of the neoconservative implications of his analysis which, to all intents and purposes, represented an alternative ideological mode of thought as opposed to a sustainable argument that ideologies had become things of the past. In any case, to argue that the age of ideological conflict is now and what remains is ideological convergence over is surely premature at a time when people all over the world are still happy to admit to being supporters of particular ideological perspectives, many of them at odds with other ways of thinking. As in the past, however, this does not mean that they agree with their fellow adherents on every issue. There has always been room for debate about the aspirations of specific ideologies and, even more commonly, about the strategies required to fulfil these aspirations. It is also worth bearing in mind that, in almost every instance, but perhaps most markedly in the case of communism, gaps exist between the ideological ideal and the reality

According to Hoberman (1984: 12), 'Sportive expressionism appeals to all ideological temperaments. In other words, it is a universal aesthetic before it is differentiated into divergent ideological messages’. However, the actual influence on and/or relevance to sport of political ideologies vary enormously. It is not the purpose of this chapter to pre-empt what follows in chapters dealing with specific ideologies. Rather the aim is to provide a discursive overview of the ways in which ideologies and sport may interact. In the case of some ideologies, the degree of influence is relatively difficult to detect although the extent to which 
the core values of these ideologies are reflected in sport is of great significance. It is clear, however, that some ideologies have sought to directly affect the ways in which sport is organised and played. In the first category, there is a place for conservatism, liberalism and socialism. Here sport is discussed as a repository of ideological thinking. In the second category, we can locate communism, fascism/national socialism, and nationalism. The focus here is on sport as a product of ideological thinking. The third category recognises that feminism and environmentalism also seek to exert influence but in rather different ways such that we can talk about sport as a site for aspirational ideological thinking.

\section{Sport as a repository of ideological thinking}

It would be fair to say that in countries such as the United Kingdom, there has been relatively little deviation on the part of mainstream political parties in relation to sport. That is not to suggest, however, that the core values which underpin these mainstream parties have little or no relevance for sport. Indeed, it can be argued that conservative ideas have been highly influential in Britain, and elsewhere, in the development of sport and in many of its current practices, to such an extent that at times it looks is as if conservatism and sport are ideally matched.

\section{(a) Conservatism}

Edmund Burke, the founding father of modern British conservatism, is almost certainly best remembered for his critique of the French Revolution. According to Burke, the revolutionaries were acting on the basis of what he described as 'abstract principles' namely liberty, fraternity, equality. In his view, this was a disastrous approach to promoting change. Of course, as a conservative, he was no great admirer of change in any circumstance. He accepted, however, that it is sometimes necessary. The important thing for Burke was 
that necessary change should always be effected cautiously. It should never be a leap in the dark which for him was precisely what change based on abstract principles involved. According to Burke, we should never overlook the value of tradition and of the tried and tested. As Hampshire-Monk (1992: 264-5) explains, ‘ Burke’s major purpose is to evoke, in a way that would have been familiar to most eighteenth-century readers, the way in which an established church, a particular kind of social order and a particular arrangement of property rights contributed to the stability of public opinion necessary for settled and civilized life’. This attitude of mind remains a fundamental element of conservative thinking and, it can be argued, it is also an ever present, albeit regularly contested, feature of sport. Tradition is highly important in the world of sport not only because many of the people most directly involved in sport, notably administrators, are themselves Burkean conservatives (perhaps with a small 'c') but also because, in certain circumstances, tradition sells.

Other elements of conservative thinking, such as respect for authority, the idea of an organic society and the inevitably of social hierarchy also have relevance for sport but these themes nan arguably be best addressed, even if indirectly, in a later discussion of socialism. For the time being, it is worth commenting on the fact that conservatives in the United Kingdom were by no means in the forefront of advocating a free market economy even though the Conservative Party has now embraced it with considerable enthusiasm. This transition is captured in the manner in which professional cricket has developed from the traditional, almost backward-looking activity that it once was to the commoditised product that it has increasingly become. The question for traditional conservatives is whether the advent of Twenty-Twenty or Big Bash cricket represents a necessary change for marketing reasons or a revolution based on abstract principles which might elad who knows where.As a socioeconomic system, capitalism owes far more to liberal economic theory, the irony being that 
modern liberals from the end of the nineteenth century onwards have been much less willing to allow free rein to market forces. What then for liberals should be the role of the state in other human endeavours, amongst them sport and leisure?

\section{(b) Liberalism}

Apart from upholding the virtues of the market economy, liberalism has had even less direct impact on sport than has conservatism. In the case of the latter, a belief in the importance of authority and order has been reflected over the years in the imposition of restrictions and even bans on specific leisure pursuits including rough-and-tumble football games and various activities involving cruelty to animals. Arguably the liberal contribution to political debate about sport has been more philosophical than ideological. My starting point here is another key figure in the history of political debate in Britain, John Stuart Mill.

Mill's On Liberty, published in 1859, appears on an initial, cursory reading to be a classic and incontestable defence of individual freedom. Mill (1974: 69) argues that 'Over himself, over his own body and mind, the individual is sovereign'. This would seem to offer each of us a considerable amount of leeway in all aspects of our lives, including the use of leisure time. However, Mill has already qualified this defence of individual freedom, having asserted that'the only purpose for which power can be rightfully exercised over any member of a civilized community, against his will, is to prevent harm to others' (Mill, 1974: 68). If the body politic is entitled to restrict out activities when harm to others is a factor, then everything hinges on how harm to others is to be defined. This is particularly relevant to the sport of (professional) boxing.

The British Medical Association espouses a long-standing policy aimed at the banning of 
boxing 'because of the serious health risks involved (British Medical Association (BMA), 2008: 2). More recently, this has been extended to apply also to Mixed Martial Arts. The number of deaths during or immediately after contests is relatively small but nevertheless significant. The incidence of non-fatal injuries is considerably greater. .The BMA claims that eighty per cent of professional boxers have serious brain scarring and many retired boxers suffer from neurodegenerative disorders. As a consequence, boxing 'cannot be justified on health and safety ground as an appropriate or legitimate sport’ (BMA, 2008: 7).

Any ensuing debate necessarily highlights the conflicted character of Mill’s defence of liberty. The overwhelming majority of professional boxers are consenting adults even if there is concern that, in many parts of the world, they are driven to this potentially dangerous activity through economic necessity. They intend to do harm to another but in so doing they accept that harm will almost certainly be done to them. Over their own bodies, are they not sovereign? On the other hand, if we extend the concept of harm and also the definition of 'the other', the argument becomes rather different. At this point, we are no longer concerned with physical harm and/or the well-being of the two combatants. Rather our concern is with the moral harm that is done to society as a whole if we accept that that two people inflicting harm on each other can be regarded as both a sport and a form of entertainment.

This is not the place, of course, to pronounce on the arguments for and against professional boxing. The purpose of the preceding discussion is simply to demonstrate the extent to which, in practice, ideologies - in this instance liberalism - can turn from being unquestioned political manuals to amalgams of sometimes mutually contradictory ideas. In the case of the next ideology to be considered, the contradictions are embedded in questions about what it wishes to achieve and how it intends to do so. 
(c) Socialism

As Berki (1975) observed, we all think we know what socialism is. According to Berki (1975: 23), 'Socialism is almost exactly coeval with classical liberalism: it is its reverse side, giving expression to the spiritual traumas and social and economic dislocations which were the effects of bourgeois-liberal victories'. For Berki, socialism is made up of four basic tendencies - rationalism, moralism, libertarianism and egalitarianism - of which the fourth is arguably the most important. All socialists would proclaim an interest in the idea of equality. But what can that possibly mean in the context of sport which almost always pits one individual against another, one team against a rival team, the end result being the emergence of winners and losers? Much depends here on what is meant by equality, the crucial distinction being between equality of reward and equality of opportunity. Whilst few socialists, let alone their critics, would argue today that winners and losers in sport should be rewarded equally or perhaps not rewarded at all, most would accept the argument that there should be equality of opportunity in relation to playing and watching sport. But even this argument is open to further qualification. Although the 'Sport for All' mantra is regularly recited in the corridors of political power and within the policy statements of sport governing bodies, this normally means that everyone, especially when they are young, should have a chance to play sport. It does not suggest that all people should have access to all sports. This is particularly significant in a country such as Britain where social class continues to cast a long shadow over people’s leisure experiences.

Nowhere was this more apparent in the past than in the distinction made between amateurs and professionals. Well into the second half of the twentieth century in Britain, the word 'amateur' was still a complimentary description someone who played sport for its own sake and according to certain standards of proper behaviour. Professionals, on the other hand, 
played sport to earn a living or to supplement an otherwise meagre income and could not be trusted to behave as honourably. But things have changed. Who, as D. J. Taylor (2006) asks, would care to be described as an 'amateur' today?

If there is one state to which the average twenty-first-century worker aspires it is the glossy, cast-iron prestige of the 'professional', with its imputations of expertise, competence and status (Taylor, 2006: 32).

But is this to suggest that elite sport must inevitably reflect the values inscribed in capitalist economics at their most stark?

It is tempting to look to the Nordic countries and, in particular, to Sweden to look for an approach that is more compatible with socialist values. Although Skille (2011: 335) is right to describe the so-called Scandinavian model as 'debatable, and debated'. He is equally correct to point out that 'historically there has been a fairly harmonic relationship between the voluntary and public sides of sport in all Scandinavian countries based on a mutual dependency' (Skille, 2011: 331) and to remind us that 'compared to most other countries, participation rates in sport are considered high in Scandinavia (Skille, 2011: 332). One can add that sport in Sweden and in the other Nordic countries has been less bedevilled than is some countries by the cult of celebrity which is so prevalent in British sport.

However, as the cultural gap between the Nordic region and the rest of the developed world grows ever narrower, it becomes much harder to maintain the distinctiveness of a system or systems which have relied so heavily on values which many might think are increasingly outmoded. Individualism constantly threatens social solidarity and cooperation. Furthermore, 
even though the Nordic countries are still worthy of emulation in the world of sport, any idea of simply importing the systems that are in place there is hopelessly idealistic (Bairner, 2010)..

\section{Sport as a product of ideological thinking}

(a) Nationalism

At the most basic level of analysis, it is easy to see the extent to which sport, arguably more than any other form of social activity in the modern world, facilitates flag waving and the playing of national anthems, both formally at moments such as medal ceremonies and informally through the activities of fans. Indeed there are many political nationalists who fear that by acting as such a visible medium for overt displays of national sentiment, sport can actually blunt the edge of serious political debate. No matter how one views the grotesque caricatures of national modes of behaviour and dress that so often provide the colourful backdrop to major sporting events, one certainly cannot escape the fact that nationalism, in some form or another, and sport are closely linked. It is important to appreciate, however, that the precise nature of their relationship varies dramatically from one political setting to another and that, as a consequence, it is vital that we are alert to a range of different conceptual issues (Bairner, 2008).

For example, like the United Nations, sport's global governing bodies, such as the International Olympic Committee or the Fédération Internationale de Football Association (FIFA), consist almost exclusively of representatives not of nations but rather of sovereign nation states. It is also worth noting that pioneering figures in the organization of 
international sport, such as Baron Pierre de Coubertin who established the modern Olympics in 1896, commonly revealed a commitment to both internationalism and the interests of their own nation states. Thus, whilst de Coubertin could write enthusiastically about a sporting event that would bring together young (male) athletes from across the globe, he was also specifically concerned with the physical well-being of young French men in the wake of a demoralizing defeat in the Franco-German War.

Whilst in most cases, these nation states that constitute international sporting bodies are coterminous with nations, the fact remains that numerous nations throughout the world, as well as other forms of collective belonging, are stateless and are consequently denied representation in international sporting competition just as they are in the corridors of global political power. When considering the relationship between sports and nationalism, therefore, it is important to think in terms both of nation states and of nations. This also provides the means whereby sport's connection with nationality and also with national identity can be separately explored. It is also useful to bear in mind that sport often acts as a window through which we are able to examine a whole range of social developments and to test a variety of theoretical concepts and perspectives. With specific reference to the relationship between sports and nationalism, observing the world of sport offers insights into the relevance and reliability of such concepts as ethnic and civic nationalism and the validity of explanatory approaches to the rise of nations and nationalism such as primordialism and modernism. Sport can also provide important insights into varieties of imperialism, the cultural politics of anti-imperialist struggle and postcolonial legacies.

(b) Communism 
Marx had nothing to say about sport per se, although Marx and Engels do make reference to the potential contribution of exercise and games to worker satisfaction (Grant, 2014). Lenin too was an advocate of physical activity which Grant (2014) appears to conflate with sport when she argues that he thereby validated the Soviet sports system. For example, Lenin advocated the establishment of a High School for Sport and Physical Culture, believing that mass participation in physical culture could help in the creation of the new 'communist man' (Bunck, 1994). However, as Grant (2014: 729) herself admits, in the years immediately following the Russian revolution, 'Competitive sport was looked upon unfavourably and did not receive official sanction until the late 1920s and 1930s'. Thus, physical activity in postrevolution Soviet Union was largely to military training or exercise for the sake of improving the health of the population. Only gradually did team sports become acceptable as vehicles of social solidarity in specific workplaces and occupational groups. The most dramatic shift in thinking arrived with the Cold War when sport was recognised as a highly effective source of what has come to be known as 'soft power'. Competition between the Soviet Union and the United States in the quest for Olympic medals became one of the most compelling narratives of the Cold War together with the space race. In pursuing sporting success, however, the Soviet Union was arguably retreating still further from the original aims of the revolution, above all an egalitarian society which did not seek to divide people into winners or losers.

Another revolutionary leader who recognised the importance of physical activity was Mao Zedong (1917) who, in one of his earliest publications, sounds more like a nineteenth-century English public school headmaster than a future communist leader, arguing that 'when the body is strong, then one can advance speedily in knowledge and morality, and reap farreaching advantages'. It is now the PRC's turn to face a similar challenge similar to that previously encountered by the Communist party of the Soviet Union, having already 
recognised the 'soft power' appeal of sport by hosting the Olympic Games in Beijing in 2008 when the country topped the medal table, having won the highest number of golds and coming second to the USA in the table for the 2012 Games held in London.

There is, of course, an additional problem linked to the inherent character of sport. Writing with specific reference to Cuba, Carter (2014: 1), argues that 'sport is often a conservative set of institutional practices used to reinforce existing power relations'. It has certainly tended to be associated far more with conservative values, such as tradition, than with radical politics. The question arises, therefore, given the trajectory described above, 'are communist ideals and sporting success compatible?'

The answer, at least in theory, is that these are not compatible objectives. As Hoberman (1984) notes, the idea of the athletic nation does not appear in Marxist writing or the rhetoric of communist societies. On the other hand, 'It is an image which still retains its primitive character and appears frequently in fascist writings (Hoberman, 1984: 72). and almost never in the rhetoric or the political literature of Marxist societies'. Moreover perhaps no single event has so clearly encapsulated the close ties between sport and ideology as the Berlin Olympic Games of 1936. As Mandell (1971: xii) asserts, "all the athletes who competed at Garmisch-Partenkirchen and at Berlin were made to feel that they were the corporeal manifestations of intellectual and political forces let loose to compete in other spheres later in that troubled decade". But why were fascists, and more specifically Nazis, with their common desire to subjugate the individual to the greater glory of the state, the race, the land, and its people, so interested in a sphere of human activity in which individual excellence is so often the central ingredient, even in team games? 


\section{(c) Fascism}

First, fascism is an essentially action-oriented ideology. Indeed, it has been credited with having invented an entirely new activist style of politics (O'Sullivan, 1983). Second, it places great emphasis on body culture. In this respect, the fascists asserted their sympathy with classical antiquity in which the human form, particularly the male form, was an object of admiration and, in some cases, adoration. Hoberman (1984: 83) comments, "no other modern political culture has produced a doctrine of physicality for its own sake". Third, the fascists were preoccupied with symbolism and, as we shall see, the symbolic power of sporting spectacle was soon identified. Finally, the fascists recognised earlier than most the propagandist potential of sport. According to Krüger (1999: 67), 'sport for the sake of national fitness and the demonstration of it was nothing new at the time of the fascist governments in Europe, but the extensive use of it for indoctrination to establish a totalitarian system was new'. The national socialists in Germany employed sport for political purposes far more than their fascist comrades elsewhere in Europe. According to Krüger (1999: 67), 'historically, the use of sport by the Nazis seems to have been the most extensive and efficient of the fascist regimes (in spite of the fact that the so-called thousand year empire lasted only twelve)’. But Hitler himself was no athlete. Conversely, Mussolini did much to present himself as an active sportsman and even a cursory examination of the Francoist years in Spain reveals evidence of the extent to which sport and, above all football, became implicated in ideological struggle (Burns, 1999). Nevertheless, it is the Nazi era that provides us most insights into the authoritarian right's close relationship with sport. 
As early as 1925, Hitler (1971) had demanded that young men should receive one hour of physical training in the morning and one hour in the afternoon daily, covering every type of sport and gymnastics. He was neither the first nor the last strict disciplinarian to recognise sport's role in personal development as such diverse experiences as those of nineteenthcentury English public schools and twentieth-century Hindu fundamentalism testify. But, as Hoberman (1984: 83) notes, 'Hitler's endorsement of the body is a specifically fascist one'.

In part, the Nazi interest in sport, like that of the communists, was related to the need for military preparedness. Indeed, throughout Europe, modern sport's development had been closely linked to military training. However, because of the Nazi belief in the superiority of the Aryan race it was vitally important, ideologically as well as strategically, to encourage physical fitness. To quote Krüger (1999: 76) again, 'the Nazis as a male-dominated cult of youth and strength, who believed in genetic and racial endowment, on the survival of the fittest, used the sports movement for their purpose on national unity’.

Although the Third Reich itself extended into the 1940s, all of the main roles that Nazism had assigned to sport were brought together in the 1936 Olympics. For example, as Mandell (1971: x) argues, 'Hitler's success as a whole is inconceivable without the application of the contrived festivity that enveloped Nazism from beginning to end'. This was expressed through a variety of vehicles which brought the militants together, helped to unify their style, and sought to win the attention and subsequently the support sympathizers. Thus, sport and other popular events became subsumed within the broader ideological enterprise. In the intervening years, the festive qualities of the Olympics and other major international competitions, particularly as revealed in a series of increasingly outrageous opening 
ceremonies, have been emphasised by every host nation. In many respects, however, the Nazis set the early pace as they did in anticipating yet another modern phenomenon - the symbiotic relationship between sport and the media. Leni Riefenstahl was commissioned to film the event in the hope that 'her cinematic record of the Nazi Olympics would bring the splendor of this unique festival to the whole German race and to the whole world' (Mandell, 1971: 251).

\section{Sport as a site for aspirational ideological thinking}

(a) Feminism

There are arguably two possible ways of viewing the current status of women's sport and of women in sport. The first is to argue that considerable advances have taken place, that the media now take women's sport more seriously than in the past, and that the future is relatively bright. The alternative view is that despite superficial appearances to the contrary, sport remains one of the last powerful bastions of patriarchy. One could add to the later that gender power relations are simply rawer in the world of sport than in areas such as politics where, in reality, advances in most countries have been few in number and relatively inconsequential. What saves the day for most professions is a kind of polite sexism. In sport, on the other hand, sexism is altogether less polite.

Take for example the failings of the National Football League to respond quickly and decisively to domestic violence meted out by some of its highly prominent players such as Ray Rice and Adrian Peters. The evidence suggests that the NFL has long ignored this subject. As Harry Edwards, emeritus professor of sociology at the University of California at 
Berkeley and adviser to the San Francisco 49ers put it, 'The NFL is essentially a moneymaking machine based on the creation of illusion and entertainment, and anything other than the marketing, growth and expansion of the game has been a low priority' (quoted in Luscombe, 2014: 33). Needless to say, this wilful neglect is by no means confined to the NFL, American football or the US in general. As Krien (2014) reveals, similar problems exist in Australian Rules football as they do in the overwhelming majority of male team sports. This is not to suggest that all men who play team sports or, indeed, sport more generally, are potential wife beaters or rapists. Nor is it to argue that such men do not exist in other walks of life. There remains something insidious, however, about a culture where some men appear to believe that the power they exude on the field of play can legitimately be transferred to their personal relationships away from sport.

By seeking to identify alternative examples of sporting heroism, Jennifer Hargreaves (2000: 3) quite properly looked beyond 'the violence, corruption, commercialization and exploitation that plague men’s sports'. In so doing, however, perhaps unwittingly, she may also have denied a voice to women as national sporting beings. The contribution of women to the relationship between sport and national identity formation has undeniably been largely ignored. This is particularly apparent in discussions on so-called national sports, including Gaelic games in Ireland, baseball in the United States and cricket in England. Just as men are customarily regarded as the real warriors who fight for their nations, so too are they identified in most of the relevant literature as proxy national warriors in the world of sport. Having identified this particular example of gender blindness, the paper goes on to outline the extent to which this problem is part of a wider theoretical and discursive disregard for the role of women in the construction and reproduction of national identities. 
Much has been made in the British media of the achievements of the country's female Olympians at London 2012 with gold medals being won in such disparate sports as rowing, boxing, dressage, cycling, and taekwondo. Commentators remarked on the fact that women were being celebrated for doing something more with their bodies than model the latest clothes. It was also noted that one of the rowing gold medallists, Heather Stanning, was a captain in the British Army and was being cheered on from afar by her battalion then serving in Afghanistan. War and sport brought together in perfect harmony, it seemed. But to what extent can we expect female athletes to assume the traditionally male role of proxy warriors who represent the nation and whose deeds are treated by many as matters of life and death?

This may, of course, be the wrong question. Rather than have as a central aim a world of sport in which women emulate men with all that this implies for good and ill, perhaps feminists should look instead towards an alternative approach to sport in which the true heroines are of the kind identified by Jennifer Hargreaves (2000: 232) who wrote that 'Different women across the world are struggling for identity, and sport has become an increasingly significant way for women to assign meaning to their lives'. This does not mean that women should treat sport as men have done. As Hargreaves (2000: 233) concludes, 'Global sport feminism is defined by difference and requires a language and strategy that takes account of difference'.

(b) Environmentalism

The emergence and subsequent development of environmentalism challenges the assumptions of those who hail the end of ideology by arguing that people are increasingly 
individualistic and have no truck with schools of thought that demand solidarity. After all, nothing could be more contrary to naked self-interest than the desire to protect the planet for future generations instead of simply ignoring such phenomena as climate change because it suits our present lifestyle to do so. The questions that environmentalists ask us to consider are as follows - Are we the masters of nature? Are we the stewards of nature? Are we equal partners with the rest of the natural world? But what is the relevance of these questions to sport?

According to Lenskjy (1998: 341), 'With the exception of golf and downhill skiing, which have regularly come under criticism for the obvious damage that they inflict on the natural environment, most sporting activities and venues escaped the attention of environmental activists and researchers until the 1980s'. Today, however, greater attention is paid to the question of what happens when sport and nature meet. As Mincyte et al (2009: 103) point out, it is important to recognise that 'nature...is intricately woven into human activities, and that human activities, including movement of sporting bodies through space and time, can and do deeply affect the environment’.

It is perhaps asking too much of sport that it become an equal partner with the natural world but one can at least hope that the people who run global sport can recognise that helping to look after the natural world is preferable to arrogantly assuming that we can do what we like with it - by building more golf courses, by holding mega events, by having Formula 1 motor racing teams travel the world at huge expense, causing considerable environmental damage along the way. 
On the positive side, the IOC has certainly begun to make the right noises about the environment with potential host cities promising sustainability and 'green Games’ being lauded. The cynic might add that most of this amounts to window dressing rather than a genuine desire to act as stewards of nature. There may certainly be a tendency to give with one hand and take away with the other. That said, it is possible that the Winter Olympics have been more successful in this regard than their summer counterparts for several reasons. First, they tend to take place in countries, such as Norway, which have relatively good environmental records. Second, they are smaller. Third, the relationship between the competitors and nature is generally more intimate than that which exists in sports that take place in outdoor stadia and indoor arenas. Good explanations all. But then there is Sochi. What hope for the environment when the Games are used by power hungry politicians with little or no concern for the environment? There is a long way to go before sport is able to meet the aspirations of environmentalism.

\section{Conclusion}

Other chapters in this collection will examine the relationship between specific ideologies and sport in detail. As revealed above, the influence on and/or relevance to sport of political ideologies vary enormously. In the case of some ideologies, the degree of influence is relatively difficult to detect although the extent to which the core values of these ideologies are reflected in sport is of great significance. It is clear, however, that some ideologies have sought to directly affect the ways in which sport is organised and played. Feminism and environmentalism also seek to exert influence but in rather different ways and to date with only limited success. Each of then still has many battles to fight. 


\section{References}

Bairner, A. (2008). Sports and nationalism. In G. H. Herb and D.H. Kaplan (eds.), Nations and Nationalism. A Global Historical Overview, Volume 3 1945-1989. Santa Barbara, California: ABC-CLIO: 991-1004,

Bairner, A. (2010). What's Scandinavian about Scandinavian sport? Sport in Society, 13 (4), 2010,

Bell, D. (1960). The End of Ideology. On the Exhaustion of Political Ideas in the Fifties. Cambridge, Mass: Harvard University Press.

Berki, R. N. (1975). Socialism. London: Dent.

British Medical Association (BMA) (2008). Boxing. An update from the Board of Science. London: BMA Science and Education Department.

Bunck, J. M. (1994). Fidel Castro and the Quest for a Revolutionary Culture in Cuba. University Park, Pennsylvania: The Pennsylvania State University Press, 1994.

Burns, J. (2009). Barca. A People’s Passion. London: Bloomsbury.

Carter, T. F. (2014). Game Changer: The Role of Sport in Revolution. International Journal of the History of Sport, 31 (7): 735-746.

Finlayson, A. (2012). Rhetoric and the Political Theory of Ideologies. Political Studies, 60 (4): 751-767. 
Fukuyama, F. (2006). The End of History and the Last Man. New York Free Press.

Fukuyama, F. (2010). The ‘End of History’. 20 Years Later. New Perspectives Quarterly, 27

(1): 7-10. http://onlinelibrary.wiley.com/doi/10.1111/j.1540-5842.2010.01124.x/epdf.

Accessed 27 July, 2015.

Grant, S. (2014) Bolsheviks, Revolution and Physical Culture. International Journal of the History of Sport, 31 (7): 724-734.

Hampshire-Monk, I. (1992). A History of Modern Political Thought. Major Political Thinkers from Hobbes to Marx. Oxford: Blackwell.

Hargreaves, J. (2000). Heroines of Sport. The politics of difference and identity. London: Routledge.

Hern, M. (2013). One Game at a Time. Why Sports Matter. Oakland, Ca: AK Press.

Heywood, A. (2003). Political Ideologies. An Introduction. Third edition. London: Palgrave Macmillan.

Hitler, A. (1971). Mein Kampf. Mumbai: Jaico Publishing House.

Hoberman, J. (1984). Sport and Political Ideology. Austin: University of Texas Press.

Krien, A. (2014). Night Games: Sex, Power and a Journey into the Dark Heart of Sport. London: Yellow Jersey Press.

Krüger, A. (1999). Strength through joy: the culture of consent under fascism, Nazism and Francoism. In J. Riordan and A. Krüger (eds.), The International Politics of Sport in the Twentieth Century, London: Spon: 67-89.

Lenskjy, H. J. (1998): Sport and Corporate Environmentalism. The Case of the Sydney 2000 Olympics. International Review for the Sociology of Sport, 33 (4): 341-354. 
Luscombe, R. (2014). Scandal and rows encircle US football as it makes its annual trip to Wembley. The Observer, 28 September: 33.

Mandell, R. D. (1971). The Nazi Olympics. New York: Macmillan

Mannheim, K. (1936). Ideology and Utopia. London: Routledge and Kegan Paul.

Mao. Z. (1917) A study in physical education. Hsin ching-nein, April

(http://www.marxists.org/reference/archive/mao/selected-works/volume-6/mswv6_01.htm)

Accessed 13 December 2010.

Mincyte, D., Casper, M. J. and Cole CL (2009). Sports, Environmentalism, Land Use, and Urban Development. Journal of Sport and Social Issues, 33 (2): 103-110.

Müller, J.-W. (2009). The triumph of what (if anything)? Rethinking political ideologies and political institutions in twentieth century Europe. Journal of Political Ideologies, 14 (2): 211226.

Mill, J. S. (1983). Fascism. London: Dent.

Skille, E. Å. (2011) Sport for all in Scandinavia: sport policy and participation in Norway, Sweden and Denmark, International Journal of Sport Policy and Politics, 3 (3): 327-339.

Taylor, D. J. (2006). On the Corinthian Spirit. The Decline of Amateurism in Sport. London: Yellow Jersey Press. 
